\title{
An Empirical Analysis of Higher Moment Capital Asset Pricing Model for Bangladesh Stock Market
}

\author{
Md. Zobaer Hasan ${ }^{1}$, Anton Abdulbasah Kamil ${ }^{1}$, Adli Mustafa ${ }^{2} \&$ Md. Azizul Baten ${ }^{3}$ \\ ${ }^{1}$ Mathematics Section, School of Distance Education, Universiti Sains Malaysia, Penang, Malaysia \\ ${ }^{2}$ School of Mathematical Sciences, Universiti Sains Malaysia, Penang, Malaysia \\ ${ }^{3}$ Department of Decision Science, School of Quantitative Sciences, Universiti Utara Malaysia, UUM Sintok, \\ Darul Aman, Malaysia \\ Correspondence: Md. Zobaer Hasan, Mathematics Section, School of Distance Education, Universiti Sains \\ Malaysia, Penang, Malaysia. Tel: 60-16-437-6054. E-mail: raihan_stat@yahoo.com
}

Received: February 25, 2013

Accepted: March 25, $2013 \quad$ Online Published: April 8, 2013

doi:10.5539/mas.v7n5p11

URL: http://dx.doi.org/10.5539/mas.v7n5p11

\begin{abstract}
Capital Asset Pricing Model (CAPM) describes a relationship which is linear between expected return and risk of an asset. Within the contents of this paper, the higher moments of return distributions for companies listed in the Dhaka Stock Exchange (DSE) market have been inspected for the period of January 2005 to December 2009. The mean-variance CAPM model is extended by taking higher moments-Skewness and Kurtosis. Monthly stock returns from 80 non-financial companies, covering ten sectors (Engineering, Food \& Allied, Fuel \& Power, Textile, Pharmaceuticals, Services \& Real Estate, Cement, Tannery, Ceramic and Miscellaneous) are studied in this research. From the empirical analysis, it is observed that the intercept term is significantly different from zero and insignificant relationship between beta and excess returns both in mean-variance CAPM and higher moment CAPM conditions. This means that the market excess returns provide no explanation for the asset rate of return, whether or not third and fourth moments are considered in the regression model. But, when the higher moments are introduced, the adjusted $R$-square increases 0.037 to 0.257 . It is noticed that the risk premium for co-skewness risk is positive for the period 2005-2009, indicating that the co-skewness risk is compensated in the DSE market for the studied period. Also, the co-kurtosis risk is rewarded by the market. Thus, in describing risk-return relationship in emerging markets like Bangladesh stock market, the higher moment CAPM performs comparatively well.
\end{abstract}

Keywords: capital asset pricing model, dhaka stock exchange, beta, co-skewness, co-kurtosis

\section{Introduction}

In the finance literature, Capital Asset Pricing Model (CAPM) is one of the most important developments. CAPM was developed by Sharpe (1964), Lintner (1965) and Mossin (1968) independently. It is the first formulation of mean-variance CAPM, which predicts that the expected return on an asset is linearly related to systemic risk.

Researchers used several methodologies to analysis the CAPM for various stock markets in the world. The studies conducted by Black (1972), Black, Jensen and Scholes (1972) and Fama and MacBeth (1973) were supportive of the standard form of CAPM. But, the standard form of CAPM was rejected, when the portfolio used to proxy for the market is inefficient (Roll, 1977; Ross, 1977). Also, Jegadeesh (1992) and Fama and French (1996) argued that because of the bad proxies of the market portfolio, the failure situation of CAPM is occurred. After 1980s, CAPM was questioned because of some remarkable abnormalities which were reported by Reiganum (1981), Elton, Martin and Rentzler (1984) and Bark (1991). Roll and Ross (1994) and Kandel, Shmuel and Stambaugh (1995) showed that an insignificant relation between risk and expected returns can produce because of the small deviations from efficiency. Isakov (1999) argued that beta may not be always a suitable risk measure in the risk-return relationship. So, financial researchers started to search for a substitute model to describe the risk-return relationship of risky assets because of the large number of empirical evidence against the CAPM. Under the mean-varianve CAPM, only two moments (mean and variance) are considered by the investors and the distribution of asset returns are assumed to be normal. Because of the asymmetric or fat tail 
distributions in the stock returns, there is a debate about the need of higher moments (skewness and kurtosis) in describing the risk-return relationship (Doan, 2007). Levy (1969) suggested that higher moments cannot be ignored even if they add little information about the shape of the distribution. Rubinstein (1973), Kraus and Litzenberger (1976), Hwang and Satchell (1999) and Ranaldo and Favre (2003) noted that when the market returns are not normal (but skewed or leptokurtic),the standard CAPM is not enough to price equity returns and they recommended for the addition of higher moments (skewness or kurtosis). Very recently, Ang, Chen and Xing (2006), Ang, Hodrick, Xing and Zhang (2006) and Xing, Zhang and Zhao (2010) suggested that the asymmetry of the returns distribution is important for asset pricing.

There were some studies related to higher moment CAPM. Fang and Lai (1997) showed that systematic variance, co-skewness and co-kurtosis contribute to the risk premium of an asset in the U.S. stock market. Dittmar (1999), Hwang and Satchell (1999) and Harvey and Siddique (2000) investigated co-skewness and co-kurtosis in emerging markets and they showed that the higher moment CAPM are better explained than the conventional mean-variance CAPM in emerging markets. Christie-David and Chaudhary (2001) employed the four-moment CAPM on the future markets and noticed that the explanatory power of the return generating process is increased in future markets. Chang, Johnson and Schill (2001) compared the four-moment CAPM with the Fama-French two factors model and observed that the SMB (the difference between the return on a portfolio of small size stocks and the return on a portfolio of large size stocks) and HML (the difference between the return on a portfolio of high book-to-market value stocks and the return on a portfolio of low book-to-market value stocks) become insignificant when the higher order moments are included. Berenyi (2002) applied the four-moment CAPM to hedge fund data and showed that volatility alone is not sufficient in measuring the risk of hedge funds for some investors. Messis, Iatridis and Blanas (2007) showed that in Athens Stock market, positive skewness is preferred by the investors for their portfolios and kurtosis risks is not to be compensated.

In this study, the effects of unconditional skewness and unconditional kurtosis will be examined. The degree of asymmetry of a distribution is represented by Skewness, where positive (negative) skewness depicts a distribution with an asymmetric tail extending toward more positive (negative) values (Harvey \& Siddique, 2000). Ignoring skewness risk in predicting stock returns causes the capital asset pricing model to devalue the risk of returns (Doan, 2007). Kurtosis portrays the relative peakness or flatness of a distribution compared with the normal distribution. Kurtosis higher (lower) than three indicates a distribution more peaked (flatter) than a normal distribution (Harvey \& Siddique, 2000). According to Hood, John, Nofsinger and Kenneth (2009) the investors dislike negative skewness and excess kurtosis because the negative skewness increases weight in the lower tail at the expense of the upper tail and the excess kurtosis increases weight in both tails at the expense of the central area of the distribution.

Research on emerging markets suggested that methods of conventional finance such as mean-variance CAPM are highly misleading (Hwang \& Satchell, 1999). But, a sound and well tested pricing model can contribute more to emerging markets for their sound operation. The objective of this study is to examine the higher moment CAPM for emerging markets, especially for Dhaka Stock Exchange (DSE) in Bangladesh. In DSE, there were several studies had been conducted. In order to test whether CAPM is a good indicator of asset pricing in Bangladesh, Rahman, Baten, and Alam (2006) considered Fama and French (1992) methodology and found that the variables have a significant relationship to the stock return. Basher, Hassan and Islam (2007) found that the DSE equity returns show negative skewness, excess kurtosis and deviation from normality. There are some actions (Hussain, Chakraborty, \& Kabir, 2008) which can improve the efficiency of the DSE market such as: ensuring asymmetric information among all investors, proper implication of rules of regulatory commission and introducing sophisticated means of investment and tools. Mobarek, Mollah, Sabur and Bhuyan (2008) searched for the independence and randomness in the return series of DSE market by using both non-parametric and parametric tests and noticed that the security returns do not follow random walk model. Alam, Yasmin, Rahman, and Uddin (2011) found that the frequency distribution of the stock prices in DSE does not follow a normal or uniform distribution.

\section{Methodology}

\subsection{Data}

The data used in the study consists of 80 non-financial companies, which are traded on the Dhaka Stock Exchange for the period of $1^{\text {st }}$ January 2005 to $31^{\text {st }}$ December 2009. Here, the period of research was 60 months, because many studies (for example, Dimson \& Marsh, 1983) used an estimation period of 60 months when using monthly returns. This study excluded the financial companies and considered only the non-financial companies because the reporting system of financial companies is quite different from non-financial companies (Mollah, 
2009). Monthly data was used for all variables, because the daily data, though better for estimating risk-return relationship, is very noisy (Basu \& Chawla, 2010). The rate of return for each security was calculated as: Return $=\ln \left(P_{t}\right)-\ln \left(P_{t-1}\right)$, where $P_{t}=$ closing price at period $t ; P_{t-1}=$ closing price at period $t-l$ and $l n=$ natural $\log$. The company's dividend, bonus and right issues were not adjusted (Lakonishok \& Smidt, 1988; Fishe, Gosnell, \& Lasser, 1993), logarithm returns were taken (Strong, 1992) and individual securities were used rather than portfolios for the analysis (Kim, 1995; Kaplanski, 2004). For a proxy of the market portfolio, the DSI Index was used and for the proxy of the risk-free asset, Bangladesh government 3-Month T-bill rate was used.

\subsection{Normality Test of Returns}

It has long been well documented that stock returns do not follow a normal distribution. The returns often have "fat tails" and more peaked than a normal distribution (Brown \& Matysiak, 2000). Bekaert, Erb, Harvey and Viskanta (1998) found that the majority of emerging country's stock returns are not normally distributed. The reasons of non-normal return distributions may be due to illiquidity, lack of divisibility, and low information transparency (Ranaldo \& Favre, 2003).

To check the normality of a sample's distribution, the prominent test: Jarque-Bera test was considered in this research. The Jarque-Bera test for normality is now presented by considering the following null hypothesis

$\mathrm{H}_{0}$ : Returns series follow the normal distribution

$\mathrm{H}_{1}$ : Returns series do not follow the normal distribution

The test statistic of JB is defined as

$$
\mathrm{JB}=\frac{\mathrm{n}}{6}\left[\mathrm{~S}^{2}+\frac{\mathrm{K}}{4}^{2}\right]
$$

where $\mathrm{n}$ is the number of observations; $\mathrm{S}$ is the skewness, and $\mathrm{K}$ is the excess kurtosis. This test follows the $\chi^{2}$ distribution with 2 degrees of freedom. The $10 \%, 5 \%$ and $1 \%$ critical value for $\chi^{2}$ is $4.605,5.991$ and 9.210 respectively. The null hypothesis of normality is rejected if the calculated test statistic exceeds a critical value from the $\chi_{(2)}^{2}$ distribution.

\subsection{Estimating the Mean-Variance CAPM}

According to the CAPM developed by Sharpe (1964), Lintner (1965) and Mossin (1968) returns can be explained through the following equation:

$$
\mathrm{R}_{\mathrm{it}}=\mathrm{R}_{\mathrm{ft}}+\beta_{\mathrm{i}}\left(\mathrm{R}_{\mathrm{mt}}-\mathrm{R}_{\mathrm{ft}}\right)
$$

where, $R_{i t}$ is the rate of return on company $i$ at time $t, R_{f t}$ is the rate of return on a risk free asset at time $t, R_{m t}$ is the rate of return on the market index at time $t$ and $\beta_{i}$ is the beta of company $i$, which can be expressed by $\operatorname{Cov}\left(R_{i}\right.$, $\left.R_{m}\right) / \operatorname{Var}\left(R_{m}\right)$. CAPM is estimated using the two-step estimation procedure: time series and cross-sectional estimation procedure (Fama \& MacBeth, 1973). In the first stage, following regression is used to estimate systematic risk:

$$
\mathrm{R}_{\mathrm{it}}-\mathrm{R}_{\mathrm{ft}}=\alpha_{\mathrm{i}}+\beta_{\mathrm{i}}\left(\mathrm{R}_{\mathrm{mt}}-\mathrm{R}_{\mathrm{ft}}\right)+\mathrm{e}_{\mathrm{it}}
$$

where $e_{i t}$ is the random disturbance term in the regression equation at time $t$. Equation (2) is estimated using ordinary least squares (OLS). In the second stage, following regression is used:

$$
\overline{\mathrm{r}}=\gamma_{0}+\gamma_{1} \beta_{\mathrm{i}}+\mathrm{e}_{\mathrm{i}}
$$

where $\overline{r_{i}}$ refers to the average excess returns for company $i$ over the whole sample, $\beta_{i}$ is the estimate of the systematic risk contained in a particular company $i$ and is obtained from the first stage regression in Equation (2), $e_{i}$ are the regression residuals. $\gamma_{0}$ and $\gamma_{1}$ are the parameter estimates.

\subsection{Estimating the Higher Moment CAPM}

From the results of the normality tests, it is observed that the empirical stock returns distribution is asymmetric and leptokurtic and for that reason the mean-variance CAPM model is to incorporate the co-skewness (third moment) and co-kurtosis (fourth moment) factors. As suggested by Kraus and Litzenberger (1976), Homaifar and Graddy (1988) and Dittmar (1999), the following equation will be derived by introducing the higher moments:

$$
\overline{\mathrm{r}_{\mathrm{i}}}=\gamma_{0}+\gamma_{1} \beta_{\mathrm{i}}+\gamma_{2} \delta_{\mathrm{i}}+\gamma_{3} \kappa_{\mathrm{i}}+\mathrm{e}_{\mathrm{i}}
$$


where the parameter $\beta_{i}$ denotes the covariance, $\delta_{i}$ represents co-skewness and $\kappa_{i}$ is co-kurtosis of asset $i$ which are time series regression coefficients of the following model:

$$
\mathrm{R}_{\mathrm{it}}-\mathrm{R}_{\mathrm{ft}}=\alpha_{\mathrm{i}}+\beta_{\mathrm{i}}\left(\mathrm{R}_{\mathrm{mt}}-\mathrm{R}_{\mathrm{ft}}\right)+\delta_{\mathrm{i}}\left(\mathrm{R}_{\mathrm{mt}}-\mathrm{R}_{\mathrm{ft}}\right)^{2}+\kappa_{\mathrm{i}}\left(\mathrm{R}_{\mathrm{mt}}-\mathrm{R}_{\mathrm{ft}}\right)^{3}+\mathrm{e}_{\mathrm{it}}
$$

The slope coefficients of the cubic CAPM model given in the above Equation (5) are used as an explanatory variable in the cross-section Equation (4) to estimate the corresponding risk premium. The coefficient $\gamma_{0}$ is intercept term and $\gamma_{1}, \gamma_{2}, \gamma_{3}$ are risk premiums for covariance risk, co-skewness risk and co-kurtosis risk. $\gamma_{1}, \gamma_{2}$ and $\gamma_{3}$ measure the required returns demanded by investors for taking on an additional unit of covariance, co-skewness risk and co-kurtosis risk.

\section{Results and Discussion}

\subsection{Summary Statistics}

Table 1. The first four momentsof monthly stock returns ofthe studied companies listed in DSE

\begin{tabular}{|c|c|c|c|c|c|c|}
\hline Company & Group & Mean (\%) & S.D.(\%) & Skewness & $\begin{array}{l}\text { Excess } \\
\text { Kurtosis }\end{array}$ & $\begin{array}{l}\text { Jarque- } \\
\text { Bera }\end{array}$ \\
\hline Aftab Automobiles & Engineering & $1.99 \%$ & $16.57 \%$ & 0.9544 & 2.0683 & $19.8030 *$ \\
\hline Aziz Pipes & Engineering & $3.37 \%$ & $14.83 \%$ & 1.0122 & 1.0575 & $13.0420^{*}$ \\
\hline Olympic Industries & Engineering & $3.19 \%$ & $14.11 \%$ & 0.5202 & 0.6073 & $3.6280^{@}$ \\
\hline Bangladesh Lamps & Engineering & $1.33 \%$ & $10.36 \%$ & -0.5972 & 2.1524 & $15.1495^{*}$ \\
\hline Eastern Cables & Engineering & $1.65 \%$ & $15.83 \%$ & 1.5833 & 4.2629 & $70.5014 *$ \\
\hline Monno Jutex & Engineering & $1.97 \%$ & $14.79 \%$ & 2.6229 & 11.1005 & $376.8514 *$ \\
\hline Monno Stafllers & Engineering & $1.49 \%$ & $16.81 \%$ & 1.9489 & 5.7975 & $122.0096^{*}$ \\
\hline Singer Bangladesh & Engineering & $0.88 \%$ & $10.93 \%$ & 2.1920 & 10.3109 & $313.8320^{*}$ \\
\hline Atlas Bangladesh & Engineering & $0.23 \%$ & $13.75 \%$ & -1.0817 & 1.6765 & $18.7272 *$ \\
\hline BD.Autocars & Engineering & $3.55 \%$ & $18.77 \%$ & 1.2801 & 2.1842 & $28.3127 *$ \\
\hline Quasem Drycells & Engineering & $1.87 \%$ & $12.01 \%$ & 0.0152 & 0.5853 & $0.8589^{@}$ \\
\hline Renwick Jajneswar & Engineering & $3.56 \%$ & $20.88 \%$ & 1.2259 & 1.8501 & $23.5857 *$ \\
\hline National Tubes & Engineering & $-0.57 \%$ & $15.72 \%$ & -1.8637 & 6.1960 & $130.7100^{*}$ \\
\hline Anwar Galvanizing & Engineering & $1.95 \%$ & $13.87 \%$ & 0.2252 & 0.3926 & $0.8926^{@}$ \\
\hline Kay \& Que & Engineering & $1.38 \%$ & $18.08 \%$ & 1.5602 & 3.6496 & $57.6396^{*}$ \\
\hline Rangpur Foundry & Engineering & $2.52 \%$ & $13.56 \%$ & 1.7739 & 6.7860 & $146.5921 *$ \\
\hline National Polymer & Engineering & $2.38 \%$ & $17.58 \%$ & -0.0587 & 2.9152 & $21.2799 *$ \\
\hline Alpha Tobacco & Food \& Allied & $-0.19 \%$ & $39.73 \%$ & -0.1536 & 19.0334 & $905.9124 *$ \\
\hline Apex Foods & Food \& Allied & $0.85 \%$ & $14.40 \%$ & 1.0358 & 3.1213 & $35.0858^{*}$ \\
\hline Bangas & Food \& Allied & $3.23 \%$ & $15.08 \%$ & 2.1931 & 6.6058 & $157.1875^{*}$ \\
\hline BATBC & Food \& Allied & $1.79 \%$ & $12.01 \%$ & 0.9612 & 3.3978 & $38.1021 *$ \\
\hline National Tea & Food \& Allied & $2.12 \%$ & $13.15 \%$ & 2.1707 & 7.6097 & $191.8886^{*}$ \\
\hline Zeal Bangla Sugar & Food \& Allied & $2.91 \%$ & $20.62 \%$ & 2.1918 & 6.6453 & $158.4397 *$ \\
\hline Bangladesh Plantation & Food \& Allied & $1.85 \%$ & $6.28 \%$ & 2.5622 & 12.3124 & $444.6393 *$ \\
\hline AMCL (Pran) & Food \& Allied & $1.59 \%$ & $11.02 \%$ & 0.7188 & 1.5064 & $10.8399 *$ \\
\hline Shaympur Sugar & Food \& Allied & $2.80 \%$ & $18.48 \%$ & 1.0593 & 0.9730 & $13.5870^{*}$ \\
\hline Rahima Food & Food \& Allied & $4.08 \%$ & $17.90 \%$ & 1.8367 & 4.2343 & $78.5589 *$ \\
\hline Meghna Pet Industries & Food \& Allied & $3.635 \%$ & $20.93 \%$ & 0.8177 & 0.6740 & $7.8221 * *$ \\
\hline
\end{tabular}




\begin{tabular}{|c|c|c|c|c|c|c|}
\hline Meghna Condensed Milk & Food \& Allied & $4.71 \%$ & $20.50 \%$ & 0.4850 & 0.2141 & $2.4667^{@}$ \\
\hline Beach Hatchery Ltd. & Food \& Allied & $3.58 \%$ & $17.47 \%$ & 1.4897 & 4.3441 & $69.3687^{*}$ \\
\hline BOC Bangladesh & Fuel \& Power & $2.02 \%$ & $10.69 \%$ & 0.7239 & 0.8007 & $6.8431 * *$ \\
\hline Padma Oil Co. & Fuel \& Power & $0.86 \%$ & $19.93 \%$ & -2.3364 & 9.3252 & $271.9837^{*}$ \\
\hline Bd. Welding Electrodes & Fuel \& Power & $4.08 \%$ & $26.33 \%$ & 2.8465 & 13.8189 & $558.4344 *$ \\
\hline Stylecraft & Textile & $1.48 \%$ & $11.31 \%$ & 2.8904 & 10.3346 & $350.5549 *$ \\
\hline Saiham Textile & Textile & $2.47 \%$ & $15.21 \%$ & 0.6608 & 1.3802 & $9.1291 * *$ \\
\hline Desh Garmants & Textile & $2.52 \%$ & $16.76 \%$ & 1.1316 & 3.9576 & $51.9613^{*}$ \\
\hline Dulamia Cotton & Textile & $1.70 \%$ & $19.68 \%$ & 1.1025 & 2.1155 & $23.3439^{*}$ \\
\hline Tallu Spinning & Textile & $1.08 \%$ & $14.14 \%$ & -0.0834 & 0.7467 & $1.4635^{@}$ \\
\hline Bextex Limited & Textile & $1.21 \%$ & $17.67 \%$ & 1.0621 & 1.4234 & $16.3454^{*}$ \\
\hline Apex Spinning. & Textile & $1.56 \%$ & $13.25 \%$ & 1.2670 & 3.6113 & $48.6549 *$ \\
\hline Delta Spinners & Textile & $3.11 \%$ & $13.16 \%$ & 1.2917 & 3.7634 & $52.0922 *$ \\
\hline Sonargaon Textiles & Textile & $2.57 \%$ & $14.52 \%$ & 0.3194 & 1.5128 & $6.7418^{* *}$ \\
\hline Prime Textile & Textile & $2.99 \%$ & $13.11 \%$ & 0.5822 & 1.5656 & $9.5173 *$ \\
\hline Alltex Ind. Ltd. & Textile & $0.79 \%$ & $15.05 \%$ & 1.2020 & 4.5504 & $66.2115^{*}$ \\
\hline H.R.Textile & Textile & $2.24 \%$ & $12.46 \%$ & 0.5269 & 1.1230 & $5.9291 * * *$ \\
\hline Square Textile & Textile & $-0.36 \%$ & $8.69 \%$ & 0.2364 & 2.0092 & $10.6507 *$ \\
\hline Metro Spinning & Textile & $2.34 \%$ & $14.74 \%$ & -0.3609 & 3.1592 & $26.2543^{*}$ \\
\hline Ambee Pharma & Pharmaceuticals & $1.93 \%$ & $15.35 \%$ & 3.8230 & 22.9213 & $1459.6194 *$ \\
\hline Beximco Pharma & Pharmaceuticals & $0.88 \%$ & $13.33 \%$ & 0.4210 & 2.2797 & $14.7647^{*}$ \\
\hline Glaxo SmithKline & Pharmaceuticals & $2.41 \%$ & $14.12 \%$ & 0.4826 & 1.0537 & $5.1050^{* * *}$ \\
\hline ACI Limited. & Pharmaceuticals & $2.59 \%$ & $12.79 \%$ & 0.5787 & 4.1257 & $45.9025^{*}$ \\
\hline Renata Ltd. & Pharmaceuticals & $2.21 \%$ & $9.29 \%$ & 0.1272 & 0.6450 & $1.2019^{@}$ \\
\hline Reckitt Benckiser Ltd. & Pharmaceuticals & $4.15 \%$ & $12.76 \%$ & 1.2923 & 2.3125 & $30.0678^{*}$ \\
\hline Therapeutics & Pharmaceuticals & $2.12 \%$ & $23.66 \%$ & 1.5604 & 4.0863 & $66.0917^{*}$ \\
\hline Pharma Aids & Pharmaceuticals & $4.51 \%$ & $14.90 \%$ & 1.1330 & 1.7996 & $20.9336^{*}$ \\
\hline The Ibn Sina & Pharmaceuticals & $1.15 \%$ & $10.67 \%$ & 0.8376 & 1.7313 & $14.5087^{*}$ \\
\hline Libra Infusions Limited & Pharmaceuticals & $1.79 \%$ & $13.22 \%$ & 0.7728 & 0.5946 & $6.8552 * *$ \\
\hline Orion Infusion & Pharmaceuticals & $2.75 \%$ & $15.09 \%$ & 1.7192 & 5.9946 & $119.3948^{*}$ \\
\hline Square Pharma & Pharmaceuticals & $-0.46 \%$ & $13.88 \%$ & -0.0362 & 2.4403 & $14.9006^{*}$ \\
\hline Beximco Synthetics & Pharmaceuticals & $1.58 \%$ & $17.77 \%$ & 1.1615 & 2.7206 & $31.9940 *$ \\
\hline Heidelberg Cement Bd. & Cement & $1.06 \%$ & $12.12 \%$ & -0.0318 & 1.4409 & $5.2008 * * *$ \\
\hline Confidence Cement & Cement & $3.59 \%$ & $14.25 \%$ & 0.4253 & 0.5221 & $2.4904^{@}$ \\
\hline Meghna Cement & Cement & $2.20 \%$ & $13.16 \%$ & 0.7224 & 1.9094 & $14.3336^{*}$ \\
\hline Niloy Cement & Cement & $1.54 \%$ & $16.07 \%$ & 1.4688 & 4.3019 & $67.8401^{*}$ \\
\hline Aramit Cement & Cement & $3.60 \%$ & $16.12 \%$ & 0.8195 & 0.8605 & $8.5670 * *$ \\
\hline Padma Cement & Cement & $3.05 \%$ & $14.87 \%$ & 1.9533 & 3.7557 & $73.4173^{*}$ \\
\hline Lafarge Surma Cement & Cement & $0.25 \%$ & $9.13 \%$ & 0.9773 & 2.1667 & $21.2875^{*}$ \\
\hline Samorita Hospital & Services \& Real Estate & $1.99 \%$ & $13.73 \%$ & 1.4126 & 5.2386 & $88.5595^{*}$ \\
\hline Information Services & Services \& Real Estate & $0.90 \%$ & $18.44 \%$ & -1.1128 & 3.1321 & $36.9083^{*}$ \\
\hline BDCOM Online Ltd. & Services \& Real Estate & $1.57 \%$ & $18.09 \%$ & 1.0491 & 5.4623 & $85.5998^{*}$ \\
\hline
\end{tabular}




\begin{tabular}{lllllll} 
In Tech Online Ltd. & Services \& Real Estate & $0.67 \%$ & $16.81 \%$ & 1.7625 & 8.1269 & $196.1809^{*}$ \\
Agni Systems Ltd. & Services \& Real Estate & $1.16 \%$ & $15.98 \%$ & 0.4776 & 0.7186 & $3.5721^{@}$ \\
Apex Tannery & Tannery & $2.19 \%$ & $14.56 \%$ & 1.1754 & 3.0154 & $36.5474^{*}$ \\
Bata Shoe & Tannery & $1.68 \%$ & $9.48 \%$ & 0.2394 & 1.7578 & $8.2981^{* *}$ \\
Apex Adelchy Footwear & Tannery & $2.55 \%$ & $17.46 \%$ & 2.2881 & 10.3583 & $320.5892^{*}$ \\
Samata Leather & Tannery & $1.80 \%$ & $19.47 \%$ & 0.6867 & 0.8088 & $6.3507^{* *}$ \\
Legacy Footwear & Tannery & $2.91 \%$ & $17.37 \%$ & 0.6611 & 0.5495 & $5.1255^{* * *}$ \\
Monno Ceramic & Ceramic & $0.59 \%$ & $13.85 \%$ & 1.6127 & 5.3855 & $98.5179^{*}$ \\
Fu-Wang Ceramic & Ceramic & $2.20 \%$ & $14.18 \%$ & 0.7700 & 2.6045 & $22.8875^{*}$ \\
Beximco & Miscellaneous & $3.50 \%$ & $20.43 \%$ & 1.1615 & 2.7206 & $31.9940^{*}$ \\
Market Return & & $1.07 \%$ & $9.02 \%$ & -0.2012 & 1.4210 & $5.4530^{* * *}$ \\
\hline
\end{tabular}

Table 1 repoeted the first four moments of monthly stock returns of 80 non-financial companies and market return of DSE market. From Table 1, it was cleared that the average returns varied from $-0.57 \%$ (National Tubes) to $4.71 \%$ (Meghna Condensed Milk). The skewness ranged from -2.33 (Padma Oil) to 3.82 (Ambee Pharma). Excess kurtosis could be as high as 22.92, ranging from 0.21 (Meghna Condensed Milk) to 22.92 (Ambee Pharma). The results reported in column 5 showed that out of the 80 companies, 69 companies exhibited positive skewness and 11 companies exhibited negative skewness. The values of excess kurtosis presented in column 6 indicated that the monthly stock returns of all companies were leptokurtic behaviour, which means that the curve was relatively more peaked than the normal curve. This findings are consistent with the findings of Mandelbrot (1963), Mandelbrot and Taylor (1967) and Campbell, Lo and Mackinlay (1998) as they showed that stock returns exhibit positive excess kurtosis (fat tail distributions). Finally, the conclusions of Bekaert et al. (1998) study match with this research as they provided evidence that out of 20 emerging stock markets, majority markets have the positive skewness and excess kurtosis. The estimates of the Jarque-Bera (JB) test given in the last column were showing that 72 stocks (out of 80 stocks) deviate from normality. Thus the main features of the studied data were: returns were positive, volatile, asymmetric and had fat tails.

3.2 Ordinary Least Squares (OLS) Estimates of Mean-Variance CAPM

Table 2. OLS Estimates of Mean-Variance CAPM

\begin{tabular}{lcccc}
\hline Variables & Coefficients & S.E. & t-value & Adj. $R^{2}$ \\
\hline Constant & $-0.026^{*}$ & 0.002 & -12.457 & 0.037 \\
Beta & $-0.016^{\circledR}$ & 0.008 & -1.999 &
\end{tabular}

$*, * *, * *$ Significance level at 1, 5, and 10\%, respectively, @ indicates insignificant, S.E. $=$ Standard Error

The critical condition of CAPM is that the intercept term $\left(\gamma_{0}\right)$ should not be significantly different from zero and there would be a positive trade off between market risk and return. But from Table 2, it was seen that the intercept term was significantly different from zero, which means that the expected retums on the zero-beta portfolio were significantly different from the risk-free rate. Also, there was an insignificant negative relationship between market risk and return, whereas for emerging markets, Thomas (1995) found a positive and insignificant risk-return association for the Bombay Stock Exchange and Mecagni and Sourial (1999) found a positive and significant risk-return relationship for Egyptian Stock Exchange. Hence, based on the intercept and slope criterion, the CAPM hypothesis could clearly be rejected for the studied individual companies in the DSE market for the reference year. 


\subsection{Ordinary Least Squares (OLS) Estimates of Higher Moment CAPM}

Table 3. OLS Estimates of Mean-Variance-Skewness CAPM

\begin{tabular}{lllll}
\hline Variables & Coefficients & S.E. & t-value & Adj. $R^{2}$ \\
\hline Constant & $-.030^{*}$ & .003 & -12.050 & \\
Beta & $-.011^{@}$ & .008 & -1.464 & .113 \\
Skewness & $.003^{*}$ & .001 & 2.779 &
\end{tabular}

*,**,*** Significance level at 1, 5, and 10\%, respectively, @ indicates insignificant, S.E. = Standard Error

Table 4. OLS Estimates of Mean-Variance-Kurtosis CAPM

\begin{tabular}{ccccc}
\hline Variables & Coefficients & S.E. & t-value & Adj. $R^{2}$ \\
\hline Constant & $-.023^{*}$ & .003 & -8.877 & \\
Beta & $-.019^{@}$ & .008 & -2.402 & .070 \\
Kurtosis & $-.001 * *$ & .000 & -1.962 &
\end{tabular}

*,**,*** Significance level at 1, 5, and 10\%, respectively, @ indicates insignificant, S.E. $=$ Standard Error

Table 5. OLS Estimates of Higher Moment CAPM

\begin{tabular}{lcccc}
\hline Variables & Coefficients & S.E. & t-value & Adj. $R^{2}$ \\
\hline Constant & $-0.027^{*}$ & 0.002 & -10.874 & \\
Beta & $-0.015^{@}$ & 0.007 & -2.105 & 0.257 \\
Skewness & $0.006^{*}$ & 0.001 & 4.514 & \\
Kurtosis & $-0.001^{*}$ & 0.0003 & -3.996 &
\end{tabular}

$*, * *, * * *$ Significance level at 1, 5, and 10\%, respectively, @ indicates insignificant, S.E. $=$ Standard Error

In order to examine the effect of higher moments on the asset pricing model, the third and fourth moments were incorporated in the mean-variance CAPM. The estimates of the mean-variance-skewness CAPM, mean-variance-kurtosis CAPM and mean-variance-skewness-kurtosis CAPM were reported for comparison in Table 3, Table 4 and Table 5 respectively. The intercept term was significantly different from zero in all cases and there was an insignificant negative relationship between systematic risk and the returns in the higher moment condition also.

All investors are aversion to variance and kurtosis and preference for (positive) skewness (Kraus \& Litzenberger, 1976). They are compensated in higher expected return for taking the systematic variance and the co-kurtosis risks whereas sacrifice the expected excess return for taking the benefit of increasing the co-skewness (Fang \& Lai, 1997). From Table 3 and Table 5, it was seen that the co-skewness coefficients were statistically significant at $1 \%$ level of significance. A significant value of $\gamma_{2}$ indicated that co-skewness was priced by the market and the excess returns of DSE market had a non-linear relationship with the market portfolio. This means that these assets will significantly increase or decrease market skewness if added to the market portfolio. The finding of this research rejected the usual market model and demonstrated the validity of the quadratic market model as a possible extension.

Since investors have preference for high skewness, negative market skewness is considered as risk and is expected to be rewarded with a positive skewness premium (Javid \& Ahmad, 2008). Theoretically, when the market returns are positively (negatively) skewed, the market premium for an asset's co-skewness with the market, $\gamma_{2}$, is negative (positive) (Lim, 1989). Therefore, from the results given in Table 3 and Table 5, the risk premium for co-skewness $\gamma_{2}$ was positive and market was negatively skewed $(-0.2012)$, which indicated that co-skewness risk was compensated in the Dhaka stock market. This finding is consistent with the findings of Messis et al. (2007), Javid (2009) and Kraus and Litzenberger (1976) studies. 
The argument for kurtosis is high kurtosis (or fat tails) is a negative investment incentive and the corresponding risk premium $\gamma_{3}$ is expected to be positive (Javid, 2009). A positive co-kurtosis coefficient means that the asset is adding kurtosis to the market portfolio. In contrast, an asset with a negative co-kurtosis coefficient means that the asset will decrease the market portfolio's kurtosis (Liow \& Chan, 2004). From the results of the Table 4 and Table 5, it was noticed that the risk premium for co-kurtosis was significant but did not had the expected sign as stock returns are negatively correlated with kurtosis. It contradicts the expectation on the relationship between kurtosis and returns for risk-averse investors, who would expect to get higher returns for higher kurtosis. The findings of this research suggested that investors were not averse to kurtosis in their portfolios and did not require higher excess rates of returns for bearing the higher co-kurtosis risks. Similar results were found by Tang and Shum (2003) for testing the Brazilian stock market and Messis et al. (2007) for testing the Athens stock market.

With the introduction of the higher moments (co-skewness and co-kurtosis) as additional explanatory variables in the regressions of stock returns, the adjusted $R^{2}$ was increased 0.037 to 0.257 . The results showed that both co-skewness and co-kurtosis were priced in the DSE market. The adjusted $R^{2}$ is higher when skewness was introduced in the model than kurtosis. So, the model with skewness was better than the model with kurtosis because it exhibited better performance (Groenewold \& Fraser, 1997).

\section{Conclusion}

This paper investigated the importance of higher moments of return distributions in capturing the variation of average stock returns for companies listed in the DSE market. The empirical findings indicated that Sharpe-Lintner standard CAPM is inadequate for Bangladesh stock market. The asset returns of DSE market deviates from normality indicated that investors were concerned about the higher moments of return distribution and this study provided strong support for the inclusion of terms that represent co-skewness and co-kurtosis. It was also found that the coefficient of determination increased as terms for coskewness and cokurtosis were included. It was shown that, in the presence of skewness and kurtosis in asset return distribution, the expected excess rate of return was related to the co-skewness and co-kurtosis but not related to the systematic variance. Therefore, non-linear asset pricing models are superior to the standard model in explaining risk return relationship. It is important for future research to develop a theoretical asset pricing model which addresses the non-normality of the return distribution.

\section{Reference}

Alam, M. M., Yasmin, S., Rahman, M., \& Uddin, M. G. S. (2011). Effect of policy reforms on market efficiency: Evidence from Dhaka Stock Exchange.Economic Research International, 2011, 8 pages. http://dx.doi.org/10.1155/2011/864940

Ang, A., Chen, J., \& Xing, Y. (2006). Downside Risk. Review of Financial Studies, 19(4), 1191-1239. http://dx.doi.org/10.1093/rfs/hhj035

Ang, A., Hodrick, R., Xing, Y., \& Zhang, X. (2006). The Cross-Section of Volatility and Expected Returns. Journal of Finance, 61(1), 259-299. http://dx.doi.org/10.1111/j.1540-6261.2006.00836.x

Bark, H. K. K. (1991). Risk, return and equilibrium in the emerging markets: Evidence from the Korean stock market. Journal of Economics and Business, 43, 353-362. http://dx.doi.org/10.1016/0148-6195(91)90031-Q

Basher, S. A., Hassan, M. K., \& Islam, M. A. (2007). Time-Varying Volatility and Equity Returns in Bangladesh $\begin{array}{lllll}\text { Stock Market. Applied } & \text { Financial Economics, } & \text { 17(17), } & \text { 1393-1407. }\end{array}$ http://dx.doi.org/10.1080/09603100600771034

Basu, D., \& Chawla, D. (2010). An empirical test of CAPM: The case of Indian stock market. Global Business Review, 11(2), 209-220. http://dx.doi.org/10.1177/097215091001100206

Bekaert, G., Erb, C. B., Harvey, C. R., \& Viskanta, T. E. (1998). Distributional characteristics of emerging market returns and asset allocation. Journal of Portfolio Management, 24(2), 102-116. http://dx.doi.org/10.3905/jpm.24.2.102

Berenyi, Z. (2002). Measuring hedge fund risk with multi-moment risk measures. Working paper, University of Munich.

Black, F. (1972). Capital market equilibrium and restricted borrowing. Journal of Business, 45(3), 444-445. http://dx.doi.org/10.1086/295472

Black, F., Jensen, M., \& Scholes, M. S. (1972). The capital asset pricing model: Some empirical findings, in: Jensen, M. ed., Studies in the theory of capital markets.pp. 79-124. New York: Praeger Publishers. 
Brown, G. R., \& Matysiak, G. R. (2000). Real estate investment: A capital market approach. UK: Financial Times Prentice Hall.

Campbell, J., Lo, A. W., \& Mackinlay, A. C. (1998). The Econometrics of Financial Markets. Macroeconomic Dynamics, 2(4), 559-562. http://dx.doi.org/10.1017/S1365100598009092

Chang, Y. P., Johnson, H., \& Schill, M. J. (2001). Asset Pricing when Returns are Non-normal:Fama-French Variables Versus Higher-Order Systematic Co-movement. Working Paper, Graduate School of Management. University of California.

Christie-David, R., \& Chaudhary, M. (2001). Co-skewness and Co-kurtosis in Future Markets. Journal of Empirical Finance, 8, 55-81. http://dx.doi.org/10.1016/S0927-5398(01)00020-2

Dimson, E., \& Marsh, P. R. (1983). The stability of UK risk measures and the problem of thin trading. Journal of Finance, 38(3), 753-783. http://dx.doi.org/10.2307/2328080

Dittmar, R. (2002). Nonlinear pricing kernels, kurtosis preference, and evidence from the cross-section of equity returns. Journal of Finance, 57(1), 369-403. http://dx.doi.org/10.1111/1540-6261.00425

Doan, P. (2007). Asset allocation under higher moments. Honours Thesis, School of Commerce, University of Adelaide, Australia.

Elton, E. J., Martin, J. G., \& Rentzler, J. (1984). The ex-dividend day behavior of stock prices: A re-examination of the clientele effect: Comment. Journal of Finance, 39(2), 551-556. http://dx.doi.org/10.2307/2327879

Fama, E. F., \& French, K. R. (1992). The cross-section of expected stock returns. Journal of Finance, 47(2), 427-465. http://dx.doi.org/10.2307/2329112

Fama, E. F., \& French, K. R. (1996). Multifactor explanations of asset pricing anomalies. Journal of Finance, 51(1), 55-84. http://dx.doi.org/10.2307/2329302

Fama, E. F., \& MacBeth, J. D. (1973). Risk, Return and Equilibrium: Empirical Tests. Journal of Political Economy, 81(3), 607-636. http://dx.doi.org/10.1086/260061

Fang, H., \& Lai, T. Y. (1997). Co-Kurtosis and Capital Asset Pricing. The Financial Review, 32(2), 293-307. http://dx.doi.org/10.1111/j.1540-6288.1997.tb00426.x

Fishe, R., Gosnell, T., \& Lasser, D. (1993). Good news, bad news, volume and the Monday effect. Journal of Business Finance \& Accounting, 20(6), 881-892. http://dx.doi.org/10.1111/j.1468-5957.1993.tb00299.x

Groenewold, N., \& Fraser, P. (1997). Share prices and macroeconomic factors. Journal of Business Finance \& Accounting, 24(9-10), 1367-1383. http://dx.doi.org/10.1111/1468-5957.00168

Harvey, C., \& Siddique, A. (2000). Conditional skewness in asset pricing tests. The Journal of Finance, 55(3), 1263-1295. http://dx.doi.org/10.1111/0022-1082.00247

Homaifar, G., \& Graddy, D. (1988). Equity Yields in Models Considering Higher Moments of the Return Distribution. Applied Economics, 20(3), 325-334. http://dx.doi.org/10.1080/00036848800000046

Hood, M., John, R. N., \& Kenneth, S. (2009). Identifying the non-normality premium of aninvestment. Managerial Finance, 35(4), 385-403. http://dx.doi.org/10.1108/03074350910935858

Hussain, T., Chakraborty, L., \& Kabir, M. A. (2008). Is Dhaka Stock Exchange efficient? An application of technical trading rule. International Conference on Recent Development in Statistical Sciences (ICSS), BCFCC, Dhaka, Bangladesh.

Hwang, S., \& Satchell, S. (1999). Modelling Emerging Market Risk Premia using Higher Moments. International Journal of Finance and Economics, 4(4), 271-296. http://dx.doi.org/10.1002/(SICI)1099-1158(199910)4:4<271::AID-IJFE110>3.0.CO;2-M

Isakov, D. (1999). Is beta still alive? Conclusive evidence from the Swiss stock market. European Journal of Finance, 5, 202-212. http://dx.doi.org/10.1080/135184799337046

Javid, A. Y. (2009). Test of Higher Moment Capital Asset Pricing Model in Case of Pakistani Equity Market. European Journal of Economics, Finance and Administrative Science, 15, 144-162.

Javid, A. Y., \& Ahmad, E. (2008). Test of multi-moment Capital Asset Pricing Model: Evidence from Karachi Stock Exchange. PIDE Working Papers 2008:49, Pakistan Institute of Development Economics, Islamabad.

Jegadeesh, N. (1992). Does market risk really explain the size effect? Journal of Financial and Quantitative Analysis, 27(3), 337-351. http://dx.doi.org/10.2307/2331323 
Kandel, S., McCulloch, R., \& Stambaugh, R. F. (1995). Bayesian inference and portfolio efficiency. Review of Financial Studies, 8(1), 1-53. http://dx.doi.org/10.1093/rfs/8.1.1

Kaplanski, G. (2004). Traditional beta, downside risk beta and market risk premiums. The Quarterly Review of Economics and Finance, 44(5), 636-653. http://dx.doi.org/10.1016/j.qref.2004.05.008

Kim, D. (1995). The errors in variables problem in the cross section of expected stock returns. Journal of Finance, 50(5), 1605-1634. http://dx.doi.org/10.2307/2329328

Kraus, A., \& Litzenberger, R. (1976). Skewness Preference and the Valuation of Risky Assets. Journal of Finance, 21(4), 1085-1094.

Lakonishok, J., \& Smidt, S. (1988). Are seasonal anomalies real? A ninety year perspective. Review of Financial Studies, 1(4), 403-425. http://dx.doi.org/10.1093/rfs/1.4.403

Levy, H. (1969). A utility function depending on the first three moments: comment. Journal of Finance, 24, 715-721. http://dx.doi.org/10.1111/j.1540-6261.1969.tb00395.x

Lim, K. (1989). A new test of the three-moment capital asset pricing model. Journal of Financial and Quantitative Analysis, 24(2), 205-216. http://dx.doi.org/10.2307/2330772

Lintner, J. (1965). The Valuation of Risk Assets and Selection of Risky Investments in Stock Portfolio and Capital Budgets. Review of Economics and Statistics, 47(1), 13-47. http://dx.doi.org/10.2307/1924119

Liow, K. H., \& Chan, L. C. W. J. (2004). Covariance, Cokewness and Cokurtosis in global real estate securities. Paper for the 5th Maastricht-Cambridge Symposium.

Mandelbrot, B. B. (1963). The variation of certain speculative prices. Journal of Business, 36(4), 394-413. http://dx.doi.org/10.1086/294632

Mandelbrot, B. B., \& Taylor, H. (1967). On the distribution of stock price differences. Operations Research, 15(6), 1057-1062. http://dx.doi.org/10.1287/opre.15.6.1057

Mecagni, M., \& Sourial, M. S. (1999). The Egyptian stock market: efficiency tests and volatility effects. IMF Working Papers 99/48, International Monetary Fund.

Messis, P., Iatridis, G., \& Blanas, G. (2007). CAPM and the efficacy of higher moment CAPM in the Athens stock market: An empirical approach. International Journal of Applied Economics, 4, 60-75.

Mobarek, A., Mollah, A., Sabur, \& Bhuyan, R. (2008). Market efficiency in emerging stock market: Evidence from Bangladesh. Journal of Emerging Market Finance, 7(1), 17-41. http://dx.doi.org/10.1177/097265270700700102

Mollah, A. S. (2009). Testing partial adjustment dividend behavioral models in emerging markets: Evidence from pre and post market reforms in Bangladesh. Global Journal of Business Research, 3(1), 1-14.

Mossin, J. (1968). Optimal Multiperiod Portfolio Policies. Journal of Business, 41(2), 215-229. http://dx.doi.org/10.1086/295078

Rahman, M., Baten, M. A., \& Alam, A. (2006). An empirical testing of capital asset pricing model in Bangladesh. Journal of Applied Sciences, 6(3), 662-667. http://dx.doi.org/10.3923/jas.2006.662.667

Ranaldo, A., \& Favre, L. (2003). How to price Hedge Funds: From two-to four-moment CAPM. Edhec Risk and Asset Management Research Center, Switzerland.

Reiganum, M. R. (1981). Misspecification of capital asset pricing. Journal of Financial Economics, 9, 19-46. http://dx.doi.org/10.1016/0304-405X(81)90019-2

Roll, R. (1977). A critique of the asset pricing theory's tests, Part I: On past and potential testability of theory. Journal of Financial Economics, 4(2), 129-176. http://dx.doi.org/10.1016/0304-405X(77)90009-5

Roll, R., \& Ross, S. A. (1994). On the cross-sectional relation between expected returns and betas. Journal of Finance, 49(1), 101-121. http://dx.doi.org/10.2307/2329137

Ross, S. A. (1977). The capital asset pricing model (CAPM), short-sale restrictions and related issues. Journal of Finance, 32(1), 177-183. http://dx.doi.org/10.2307/2326912

Rubinstein, M. (1973). The Fundamental Theorem of Parameter Preference Security Valuation. Journal of Financial and Quantitative Analysis, 8(1), 61-69. http://dx.doi.org/10.2307/2329748

Sharpe, W. F. (1964). Capital Asset Prices: A Theory of Market Equilibrium under Conditions of Risk. Journal of Finance, 19(3), 425-442. http://dx.doi.org/10.2307/2977928 
Strong, N. (1992). Modeling abnormal returns: A review article. Journal of Business Finance and Accounting, 19(4), 533-53. http://dx.doi.org/10.1111/j.1468-5957.1992.tb00643.x

Tang, G., \& Shum, W. (2003). The conditional relationship between beta and returns: Recent evidence from International Stock Markets. International Business Review, 12(1), 109-126. http://dx.doi.org/10.1016/S0969-5931(02)00090-2

Thomas, S. (1995). Heteroskedasticity models on the Bombay stock exchange. PhD Dissertation, University of Southern California.

Xing, Y., Zhang, X., \& Zhao, R. (2010). What does the individual option volatility smirk tell us about future equity returns? Journal of Financial and Quantitative Analysis, 45(3), 641-662. http://dx.doi.org/10.1017/S0022109010000220 